\title{
Species richness, spatial distribution and colonisation pattern of algal and invertebrate epiphytes on the seagrass Amphibolis griffithii
}

\author{
Michael A. Borowitzka, Roger C. Lethbridge, Lorna Charlton \\ School of Biological and Environmental Sciences, Murdoch University, Murdoch 6150, Western Australia
}

\begin{abstract}
The distribution of epiphytic algae and sessile invertebrates on the seagrass Amphibolis griffithii is not random. The number of epiphyte species increases with increasing seagrass height and there are approximately twice as many epiphytic algal species as invertebrate species. Epiphytes growing on the stems have a clear apico-basal distribution, with algae such as Haliptilon roseum, Laurencia filiformis and Hypnea spp. most abundant on the upper $30 \%$ of the seagrass stem, while the bryozoan Celleporina sp and the hydrozoan Thyroscyphus marginatus are most abundant near the base of the stem. Other species of algae and invertebrates have intermediate distributions. Epiphyte biomass increases with seagrass height and the bulk occurs on the uppermost $20 \mathrm{~cm}$ of the tallest plants. This is mainly due to 1 or 2 algal species. Recruitment of epiphytes also follows a distinct pattern related to plant size (age), with species such as the crustose coralline algae rapidly colonising the leaves and stems of new seagrass plants. Other very early colonisers are the bryozoans Pyripora polita and Electra flagellum on the stems, and the hydrozoan Plumularia compressa and the bryozoan Thairopora mamillaris on the leaves.
\end{abstract}

\section{INTRODUCTION}

Stands of the seagrass Amphibolis antarctica (Labillardiere) Sonder et Ascherson ex Ascherson and $A$. Griffithii (J. M. Black) Den Hartog (Potamogetonales, Cymodoceaceae) are very common in the shallow waters of southern and southwestern Australia (Kirkman \& Walker 1989). A. antarctica occurs from Carnarvon, Western Australia (245' S) to Wilson's Promontory, Victoria $\left(39^{\circ} 00^{\prime} S\right)$, whereas A. griffithii has a more restricted distribution from Kalbarri, Western Australia $\left(27^{\circ} 40^{\prime} \mathrm{S}\right)$ to Victor Harbour, South Australia $\left(35^{\circ} 30^{\prime} \mathrm{S}\right)$ (Ducker et al. 1977, Borowitzka pers. obs.). Unlike most other seagrasses, Amphibolis species have lignified, long-lived, upright stems and these stems, as well as the terminal leaf clusters, provide excellent substrata for many large epiphytic algae and invertebrates.

As first reported by Harvey $(1847,1855)$, the epiphytic biota of Amphibolis spp. are very diverse. Ducker et al. (1977) recorded 116 epiphytic algae and 20 species of invertebrates epiphytic on Amphibolis, and noted that their species list was undoubtedly not comprehensive. Amphibolis is a major habitat for many of these species, but most are also found on adjacent algae or grow epilithically; only a few algae (Dicranema revolutum (C. Ag.) J. Ag., D. cincinnalis Kraft and Metagoniolithon stelliferum (Lamarck) Weber van Bosse), and invertebrates (Stenochiton cymodocealis and Campanularia tincta) grow exclusively, or almost exclusively, on Amphibolis. The turnover and biomass production of the epiphytic biota contributes significantly to the primary production of the Amphibolis ecosystem (Ducker et al. 1977), and thus to the highly productive shallow coastal ecosystems of southern and southwestern Australia. The epiphytes are also an important food resource and habitat for many fish, the western rocklobster Panulirus cygnus and many other invertebrates (Joll \& Phillips 1984, Nichols et al. 1985, Howard et al. 1989, Klumpp et al. 1989).

Aside from their importance as food and shelter, Amphibolis and its epiphytes also provide a 'natural' model for the study of settlement, recruitment and competition between sessile marine algae and invertebrates. The rather constant morphology of Amphibolis stems and leaves over its geographical range make it particularly suitable for studies of this type.

This paper describes the spatial distribution of epiphytes on the seagrass, and the influence of plant 
size and age on the pattern of colonisation and species richness of the epiphytic biota, and provides base-line data for further studies of the temporal and spatial dynamics of the epiphytic populations.

\section{MATERIALS AND METHODS}

Stand of Amphibolis griffithii were sampled between July and November 1983 at 3 sites in Western Australia; one adjacent to Penguin Island near Fremantle (ca $115^{\circ} 41^{\prime} \mathrm{E}, 32^{\circ} 19^{\prime} \mathrm{S}$ ), one at Seven Mile beach near Dongara (ca $114^{\circ} 55^{\prime} \mathrm{E}, 29^{\circ} 22^{\prime} \mathrm{S}$ ) and one at Two

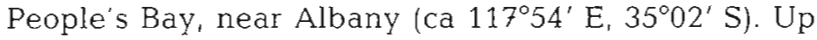
to eight $0.25 \mathrm{~m}^{2}$ quadrats were placed in a predetermined pattern around a randomly selected point in a homogeneous bed of $A$. griffithii at about 2 to $3 \mathrm{~m}$ depth. All plants within each quadrat were cut off just above the substratum with scissors and transported to the laboratory where they were either preserved in $6 \%$ $(\mathrm{v} / \mathrm{v})$ neutralised formalin in seawater, or frozen at $-20^{\circ} \mathrm{C}$ until analysis.

Reference samples of all algal species collected are housed in the Murdoch University herbarium (MURU).

Epiphyte diversity and patterns of colonisation. Epiphyte diversity: In order to assess the diversity of epiphytes on Amphibolis griffithii plants of different size, seagrasses from quadrats collected at Penguin Island and Seven Mile Beach in September 1983 and at Two People's Bay in November 1983 were sorted into $10 \mathrm{~cm}$ height-interval size classes. Ten plants from each size class were taken at random from each quadrat and their stems and leaves separated for analysis. The number of species of epiphytic algae and sessile invertebrates associated with the stems and leaves were then plotted against the height of each $A$. griffithii plant.

Patterns of colonisation: An insight into the pattern of colonisation of stems and leaves by species occurring in samples from the above collections was obtained by examining the taxa present on all plants in each quadrat. Presence and absence data for each species were then plotted against the heights of the plants in the samples.

Biomass of stems, leaves and epiphytes versus plant height. After inspection of the 10 plants in each size class used to determine epiphyte diversity, all macroscopic epiphytic species, except encrusting coralline algae, were removed with jeweller's forceps. The number of branches on each plant was counted, and the dry weight of the cleaned stems and leaves determined.

All algae from each plant, other than encrusting coralline algae, were separated into species for dry weight determinations. The encrusting coralline algae and small epiphytic invertebrates did not permit meaningful dry weight measurements and were recorded only as present or absent.

The number of branches, and dry weights of stems, leaves and macroalgal epiphytes for plants in each size class were plotted as scattergrams against plant height.

Epiphyte distribution on stems and leaves. The distribution of epiphytic organisms on the stems and leaves was analysed in detail using the November 1983 samples from Penguin Island. Distribution patterns of the algae were based upon 30 randomly selected Amphibolis stems, whereas for the less numerous invertebrates 60 stems were employed. After removing the leaves for separate analysis, each of the stems was cut into 10 equal portions, i.e. into percentiles.

Macroalgae were removed from each percentile division, sorted into species, and their wet weight recorded to the nearest $0.1 \mathrm{~g}$. Blotted wet weights were used because the quantities of many algal species associated with each percentile division were frequently too small to yield more accurate dry weight measurements. Macroalgae present on the leaves were also assessed from their blotted wet weight.

The different growth habits and phenology of other epiphytic organisms required different methods of analysis. Thus, the area covered by encrusting coralline algae and bryozoan colonies ensheathing the stems were assesseds visually and scored on a 0 (absent) to 20 (total cover) scale. Quantitative data on the stem hydroids [Stereotheca elongata (Lamouroux), Aglaophenia plumosa Bale, Thyroscyphus marginatus (Bale)] were obtained by counting the number of fans or erect colonies associated with each percentile division.

The predominant hydroids (e.g. Plumularia compressa) and encrusting bryozoans (e.g. Thairopora mamillaris) on the leaves were quantified by counting the number of leaves per plant that possessed colonies of these species. Small, discrete colonies (e.g, the bryozoan, Lichenopora sp.) and non-colonial organisms (e.g. Spirorbis sp.) were counted individually.

\section{RESULTS}

\section{Epiphyte diversity and patterns of colonisation}

To date, we have recorded over 150 species of multicellular algae and over 40 species of sessile invertebrates that grow epiphytically on Amphibolis griffithii at the 3 study sites. Only a small number of these species were routinely observed on individual plants because the majority of epiphytes were patchily distributed between plants and between sites.

The number of species of epiphytic algae at all 3 sites 

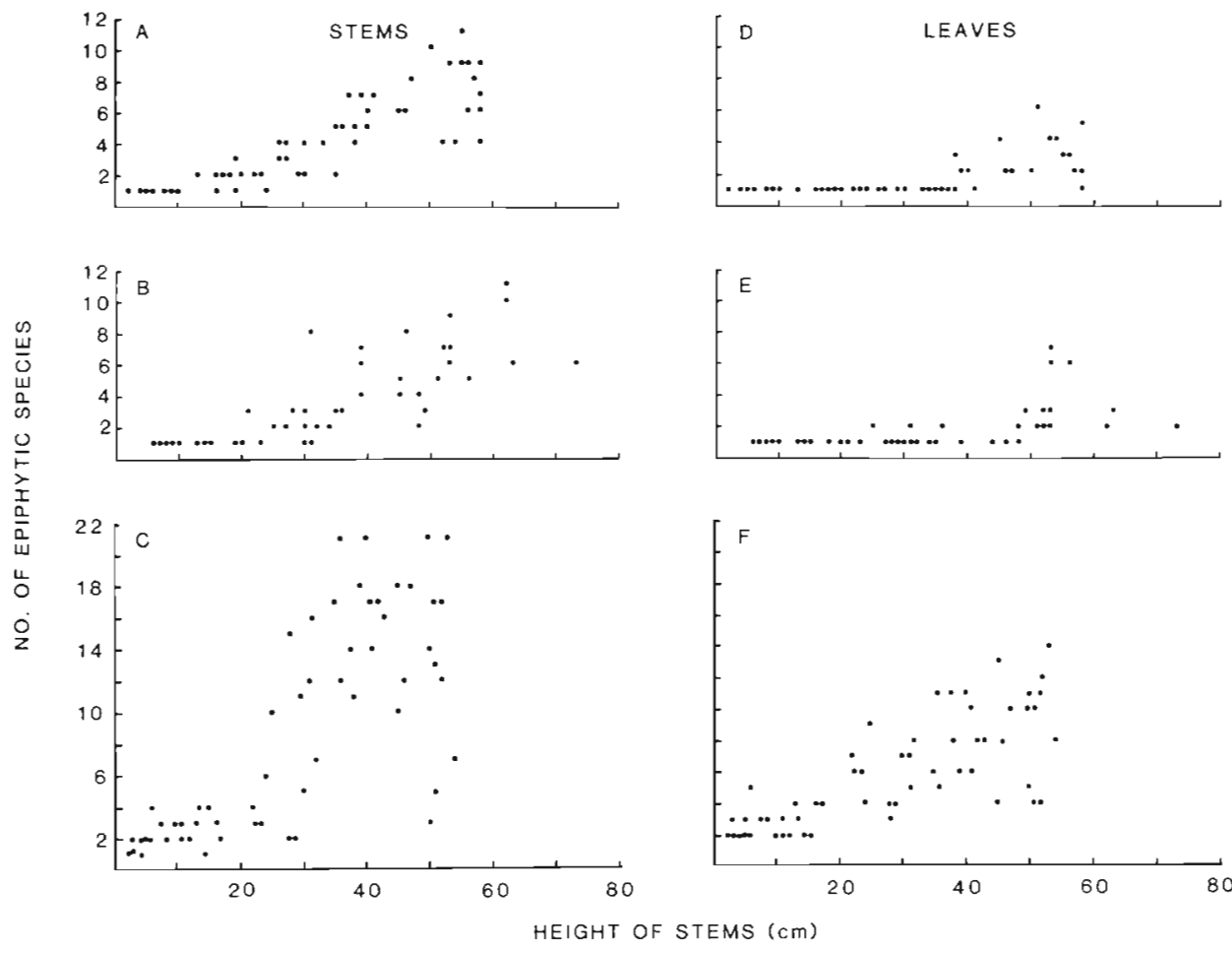

Fig. 1. Numbers of species of algae epiphytic on plants of Amphibolis griffithii of different height. (A, D) Seven Mile Beach site, September 1983; (B, E) Penguin Island site September 1983; (C, F) Two People's Bay site, November 1983

Table 1. Number of species of epiphytic organisms on Amphibolis griffithsii stems and leaves in $0.25 \mathrm{~m}^{2}$ quadrats (Penguin Island, November 1983)

\begin{tabular}{|c|c|c|c|c|c|c|}
\hline \multirow{3}{*}{$\begin{array}{c}\text { Quadrat } \\
\text { no. }\end{array}$} & \multicolumn{6}{|c|}{ Numbers of species } \\
\hline & Ste & & Lea & ves & Tot & tal \\
\hline & Inverts. & Algae & Inverts. & Algae & Inverts. & Algae \\
\hline 1 & 8 & 38 & 3 & 25 & 11 & 42 \\
\hline 3 & 11 & 29 & 3 & 20 & 13 & 38 \\
\hline 4 & 10 & 34 & 2 & 18 & 12 & 36 \\
\hline 5 & 8 & 36 & 2 & 19 & 10 & 41 \\
\hline 8 & 12 & 39 & 3 & 24 & 15 & 47 \\
\hline
\end{tabular}

(Fig. 1, Table 1) exceeded the number of species of epiphytic sessile invertebrates (Fig. 2, Table 1), and more epiphytic species were associated with the seagrass stems than with the leaves. There were up to twice as many epiphytic algal species on stems compared to the leaves, whereas the number of epiphytic invertebrate taxa showed little difference between these substrata (Table 1, Fig. 2) except in November when the overall diversity increased markedly, especially on the stems. Few species of epiphytes, especially invertebrates, were common to both stems and leaves

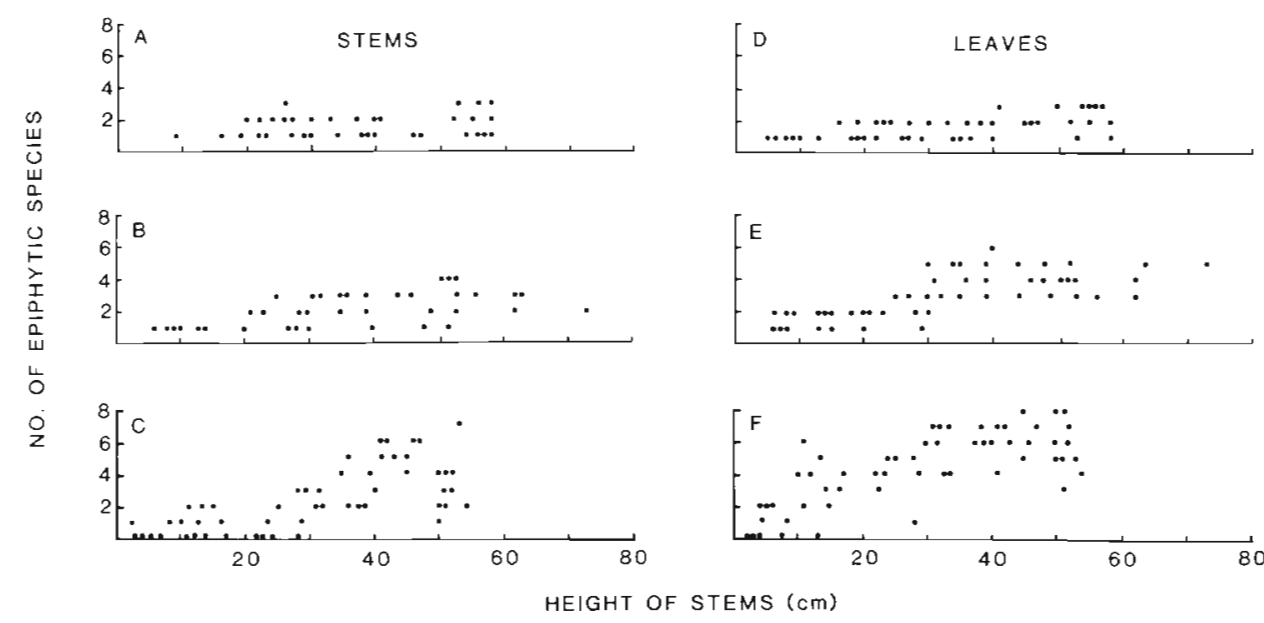

Fig. 2. Numbers of species of sessile invertebrates epiphytic on plants of Amphibolis griffithii of different height. (A, D) Seven Mile Beach site; (B, E) Penguin Island site; $(C, F)$ Two People's Bay site. Same quadrats as for Fig. 1 
There was a clear relationship between the number of epiphytic species recorded at each site and the heights of the Amphibolis griffithii plants (Figs. 1 and 2). Thus, the maximum diversity of epiphytic algae was recorded on plants whose height was within 10 to $20 \mathrm{~cm}$ of the tallest individuals in the stand. Epiphytic invertebrates, however, approached or reached their maximum diversity on smaller plants. A reduced number of epiphytic algal species occurred on both the stems and leaves of the tallest Amphibolis plants in the quadrats (Figs. 1 and 2).

Since plant height is a function of plant age, the pattern of recruitment of epiphytic organisms can be observed by plotting the presence or absence of individual species in the samples against plant height (Fig. 3). The initial colonisers observed on the stems and leaves of 2 to $4 \mathrm{~cm}$ tall plants were mainly Fosliella cymodoceae (Foslie) Jones \& Woelkerling, F. cruciata Bressan, and Pneophyllum caulerpae (Foslie) Jones \& Woelkerling. Almost simultaneously, the bryozoans Pyripora polita (Hincks) and Electra flagellum (MacGillivray) were recruited on the stems, and the hydrozoan Plumularia compressa and the bryozoan Thairopora mamillaris appeared on the leaves. Various sponges were also found at times on the stems and leaves of small plants. Older Amphibolis griffithii plants that exceeded a height of ca $15 \mathrm{~cm}$ were further colonised by other algae such as Dicranema revolutum, $D$. cincinnalis, Hypnea spp., Gloiosaccion brownii Harvey and Rhodymenia australis Sonder, as well as by the bryozoan Adeonellopsis portmarina (Maplestone). The polychaete Spirorbis sp., the bryozoan Lichenopora sp., and the red alga Ceramium puberbulum Sonder occurred on the leaves of these plants. Taller seagrasses ( $>30 \mathrm{~cm}$ ) were further colonised by numerous other species of algae and invertebrates, with Laurencia filiformis and the coralline algae Haliptilon roseum and Metagoniolithon stelliferum almost always occuring (Fig. 3).

There is clearly some seasonality in species diversity, with a clear increase in epiphyte species number in early summer (November) samples compared to the winter and spring samples (Table 2). Most of the additional species were very patchily distributed among the quadrats, and the increase in invertebrates was mainly due to sponges.

\section{Biomass of stems, leaves and epiphytes versus plant height}

The relationships betwen these variables were determined from September 1983 samples from Penguin Island and are shown in Fig. 3. Similar results were also obtained at the other 2 sites.
As the Amphibolis griffithii plants increased in height the stems became more branched (Fig. 4A), and their dry weight increased progressively (Fig. 4B). Since $A$. griffithii stems and branches are remarkably uniform in diameter along their whole length, their dry weight is essentially a linear index of stem surface area. Taller plants therefore possessed a larger stem and branch surface area for colonisation by epiphytic organisms.

The dry weight of the leaves is also an index of the surface area available for epiphytic colonisation. In our samples leaf dry weight was more variable than stem dry weight, but also increased with increasing plant height (Fig. 4C). This is due to the fact that each branch is normally terminated by a leaf cluster, and these leaf

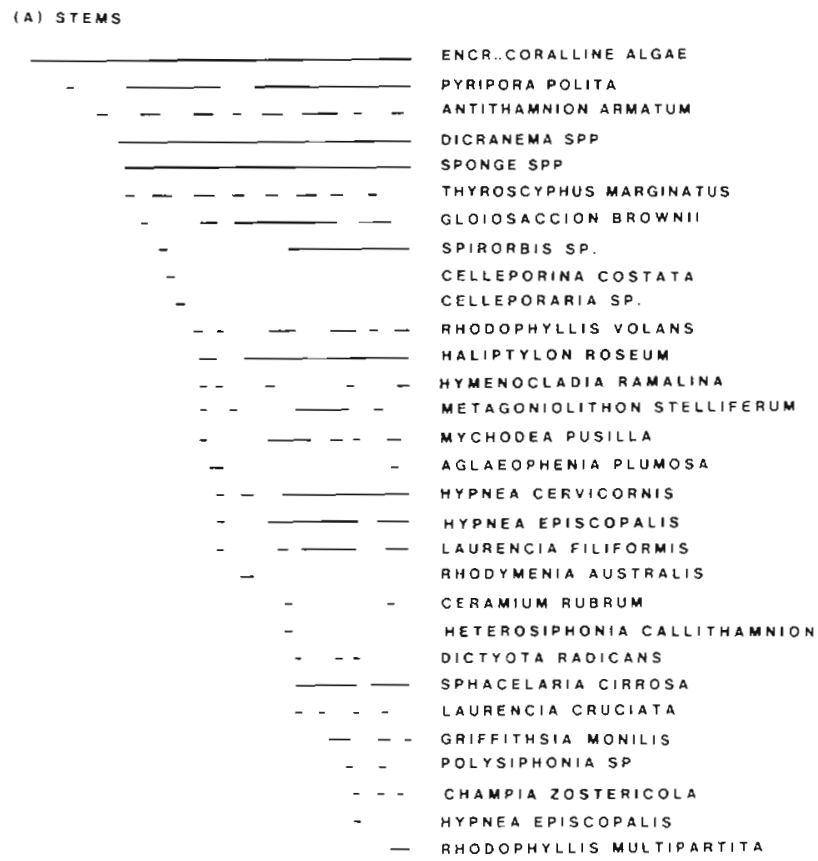

(B) LEAVES

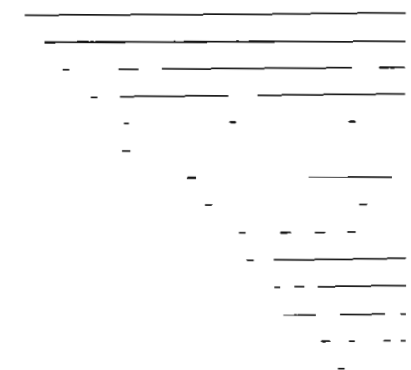

ENCR, CORALLINE ALGAE DLUMULAFIA COMPRESSA THAIROPORA MAMMILARIS SPIROREIS SP. SPONGE SPP. ELECTRA FLAGELLUM LAURENCIA CAUCIATA LICHENOPORA SP HALIPTYLON ROSEUM CERAMIUM DUPERBULUM ANOTRICHIUM? ELONGATUM GRIFFITHSIA MONILIS JANIA SP LAUAENCIA FILIFORMIS SPHACELARIA CIRROSA

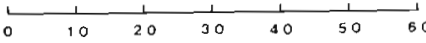

HEICHT OF SEAGRASS PLANT (cm)

Fig. 3. Distribution of epiphytic organisms on (A) stems and (B) leaves of Amphibolis griffithil plants of different height. Data pooled from 150 plants from Penguin Island (September 1983)

Species of crustose coralline algae have been combined 
Table 2. Total algal species per $0.25 \mathrm{~m}^{2}$ quadrat

\begin{tabular}{|c|c|c|c|c|}
\hline Site & Month & Mean $\pm S E$ & Range & $\begin{array}{c}\text { No. } \\
\text { quadrats }\end{array}$ \\
\hline Dongara & Sep & $18.25 \pm 1.75$ & $15-21$ & 8 \\
\hline Penguin Isl. & Jul & $23.17 \pm 2.48$ & $19-26$ & 6 \\
\hline Penguin Isl. & Nov & $40.80 \pm 4.21$ & $36-47$ & 5 \\
\hline
\end{tabular}

clusters are of fairly uniform size. The linear regression equation between branch number and leaf weight, calculated for 150 stems collected at Seven Mile Beach, in September 1983 was

$$
\text { Leaf dry wt }=-0.152+0.158 \text { Branch no. }
$$

with a correlation coefficient of 0.8114 . The reduction in leaf dry weight observed in the tallest plants (Fig. 4C) was due to the loss of some terminal leaf clusters from these plants, presumably due to the higher drag that the tallest plants are exposed to.
The biomass of the epiphytic algae was not correlated with the number of taxa on each plant (compare Figs. 1B, 1E and 4D), nor directly related to the increasing height of the seagrass (Fig. 4D). The biomass of the epiphytic algae remained fairly low and constant with increasing seagrass height until the Amphibolis griffithii plant reached a size within 10 to $20 \mathrm{~cm}$ of the maximum height of the seagrass stand (Fig. 4D). Once this size was reached, there was a sudden and very pronounced increase in epiphytic algal biomass. The biomass of the epiphytic algae on the talles plants often equalled that of the seagrass itself, and more than $80 \%$ of the total algal biomass was restricted to the apical $40 \%$ of the stems.

The increase in epiphyte biomass on these taller stems was due to the proliferation of only 1 or 2 species of algae on each stem. Major contributions to the algal biomass varied between quadrats and sites but were usually made by Laurencia filiformis, Haliptilon roseum, Hypnea spp., Dicranema spp. and Metagonio-
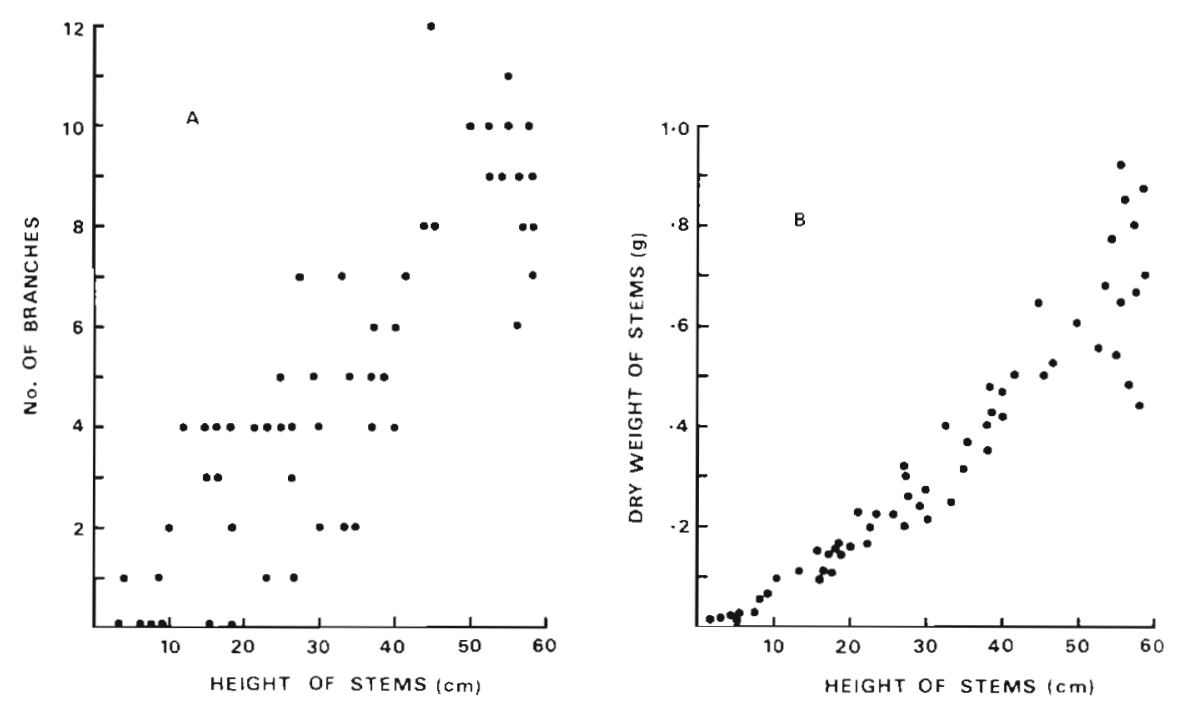

Fig. 4. Amphibolis griffithii. (A) Numbers of branches per plant with increasing height of seagrass; (B) dry weight of stems of different height; (C) dry weight of leaves from stems of different height; (D) total dry weight of epiphytic algae on individual plants of increasing height. All samples from Penguin Island site, September 1983
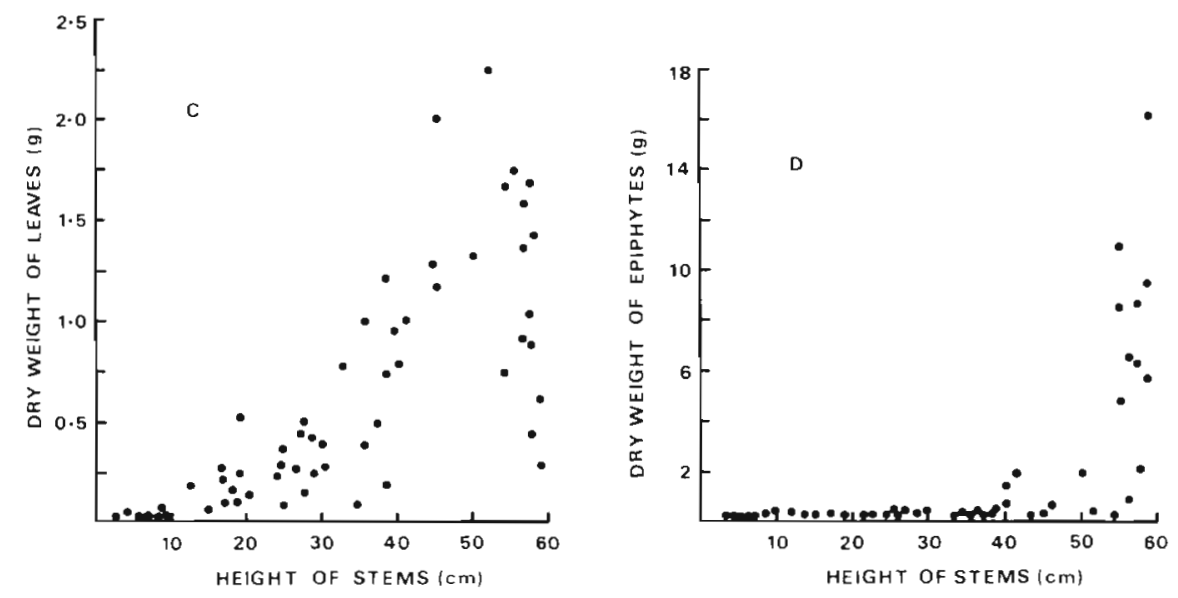
Table 3. Distribution of mean biomass among algal species epiphytic on Amphibolis griffithsii at Penguin Island (November 1983), in four $0.25 \mathrm{~m}^{2}$ quadrats. (N.B. Crustose coralline algae are not listed since their dry weight could not be determined accurately)

\begin{tabular}{|c|c|c|c|}
\hline Species & Mean dry wt $\pm \mathrm{SE}$ & Range & \\
\hline Metagoniolithon stelliferum & $7.395 \pm 4.399$ & $(3.218-13.538)$ & \\
\hline Laurencia filiformis & $5.855 \pm 3.175$ & $(1.649-9.048)$ & \\
\hline Plocamium mertensij & $0.789 \pm 1.344$ & $(0.011-2.797)$ & \\
\hline Haliptilon roseum & $0.700 \pm 0.083$ & $(0.589-0.786)$ & \\
\hline Hymenocladia ramalina & $0.614 \pm 0.382$ & $(0.224-0.964)$ & \\
\hline Hypnea cervicornis & $0.401 \pm 0.441$ & $(0.064-1.049)$ & \\
\hline Heterosiphonia callithamnion & $0.366 \pm 0.239$ & $(0.206-0.723)$ & \\
\hline Dicranema revolutum & $0.165 \pm 0.097$ & $(0.057-0.287)$ & \\
\hline Rhodymenia australis & $0.162 \pm 0.083$ & $(0.043-0.230)$ & \\
\hline Dictyota radicans & $0.124 \pm 0.209$ & $(0.011-0.438)$ & \\
\hline Gloiosaccion brownii & $0.109 \pm 0.124$ & $(0.031-0.292)$ & \\
\hline Dasyclonium incisum & $0.093 \pm 0.074$ & $(0.018-0.193)$ & \\
\hline Haloplegma preissi & $0.082 \pm 0.036$ & $(0.048-0.130)$ & \\
\hline Polysiphonia amphibolis/Polysiphonia forfex & $0.056 \pm 0.035$ & $(0.015-0.098)$ & \\
\hline Champia zostericola & $0.029 \pm 0.156$ & $(0.015-0.051)$ & \\
\hline Chaetomorphasp. & $0.022 \pm 0.028$ & $(0.001-0.064)$ & \\
\hline Craspaedocarpus tenuifolius & 0.022 & $(0.009-0.064)$ & {$[3]^{a}$} \\
\hline Mychodea marginifera & 0.017 & $(0.009-0.058)$ & {$[2]$} \\
\hline Mycodea australis & 0.009 & $(0.040-0.309)$ & {$[2]$} \\
\hline Bryopsis plumosa & 0.006 & $(0.001-0.015)$ & [3] \\
\hline Ulva rigida & 0.006 & $(0.001-0.015)$ & [3] \\
\hline Bornetia binderiana & 0.006 & $(0.009-0.015)$ & {$[2]$} \\
\hline Griffithsia monilis & 0.004 & & {$[1]$} \\
\hline Lenormandia spectabilis & 0.004 & & [1] \\
\hline Antithamnion armatum & 0.004 & & [1] \\
\hline Ceramialean alga & 0.004 & & [1] \\
\hline Codium sp. & 0.002 & & {$[1]$} \\
\hline
\end{tabular}

Iithon stelliferum (Table 3). In the sample illustrated in Fig. 4D, the increase in dry weight of the epiphytes growing on Amphibolis griffithii plants greater than $50 \mathrm{~cm}$ high was mainly due to $H$. roseum. Thus, much of the dry weight was $\mathrm{CaCO}_{3}$ since the organic content of this alga is only ca $40 \%$ of total dry weight as determined by ashing at $650^{\circ} \mathrm{C}$.

\section{Epiphyte distribution on stems and leaves}

The different epiphytic species clearly recruit successfully to different parts of the Amphibolis griffithii plant. Detailed analyses of the stems and leaves were therefore undertaken in order to quantify this differential recruitment.

\section{Stems}

Individual algal species sampled at Penguin Island in November 1983 varied in their distribution on the seagrass stems (Fig. 5). Although most abundant in the mid-region, the encrusting coralline alga Fosliella cymodocaeae regularly occurred along the whole length of the stem. Other algal species exhibited a more restricted distribution. Thus, the branched, fleshy algae such as Laurencia filiformis, Hypnea spp. and Polysiphonia spp. occurred mainly on the upper $30 \%$ of the stem (Fig. 5) whereas Rhodophyllis multipartita, Haliptilon roseum and Champia zostericola sp. were most abundant just below this level (Fig. 5). Other common red algae such as Dicranema spp. and Gloiosaccion brownil occurred over a wider region of the stem, but were still most abundant on its upper half.

The most common sessile invertebrates on the stems of Amphibolis griffithii were 3 colonial hydroids (Aglaophenia plumosa, Stereotheca elongata and Thyrosyphus marginatus) and 2 bryozoans (Electra flagellum MacGillivray, and Pyripora polita). A. plumosa and $S$. elongata are both characterised by creeping stolons that give rise to erect, symmetrical and fan-shaped colonies from which the polyps emerge. Both species occurred within all percentile divisions of the stems amongst and between tufts of macroalgae. They were usually more common in the mid-stem region (Fig. 6). I marginatus was the least common of the stemdwelling hydroids and exhibited a marked predeliction for the basal parts of the stem (Fig.6). When 2 or more hydroid species inhabited the same stem, they were 

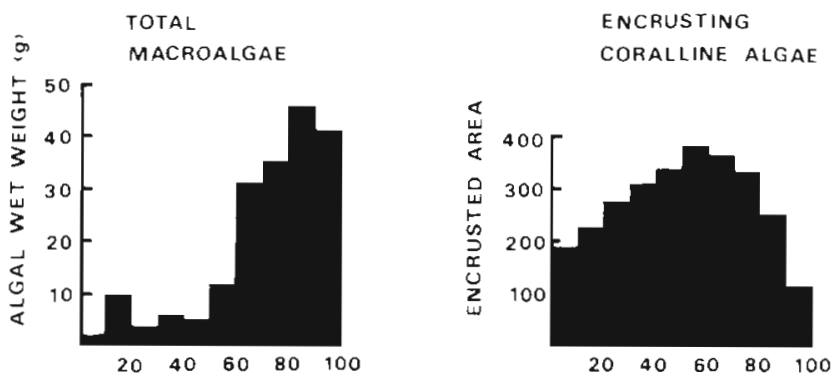

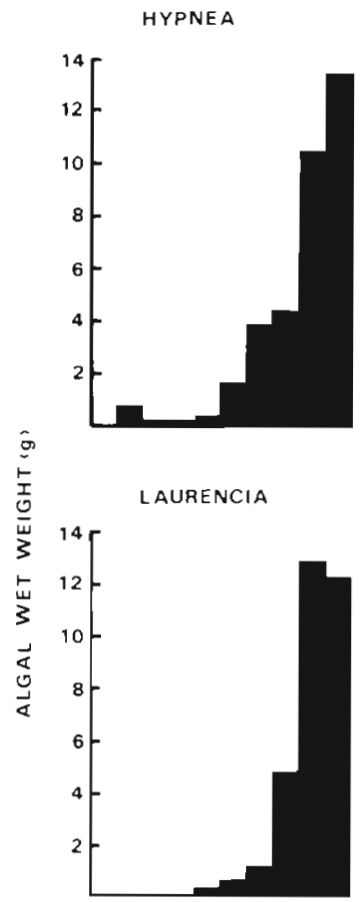

POLYSIPHONIA

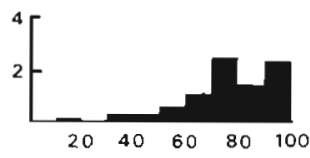

HALIPTILON

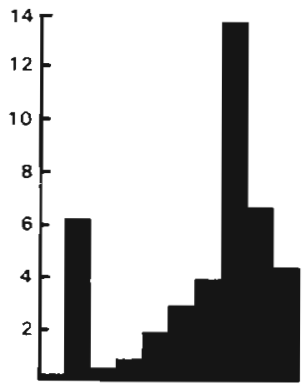

RHODOPHYLLIS

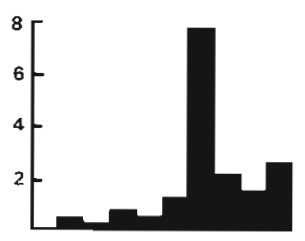

DICRANEMA

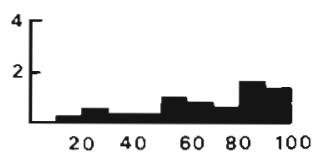

$\begin{array}{lllll}20 & 40 & 60 & 80 & 100\end{array}$

PERCENTILE DIVISIONS OF STEMS usually located within different percentile divisions and rarely overlapped (Fig. 6).

The bryozoans Electra flagellum and Pyripora polita are superficially similar in appearance, but the skeleton of E. flagellum is less calcified and apparently much more flexible than that of $P$. polita. This may account for the wider distribution of E. flagellum on the upper divisions of the seagrass stem (Fig. 7), where water motion and flexing of the stem are much greater. Although considerably rarer, 4 other bryozoans were associated with Amphibolis griffithil stems. Adeonellopsis portmarina (Maplestone) formed foliose and
CHAMPIA

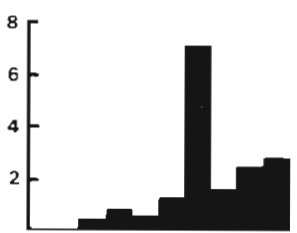

GLOIOSACCION

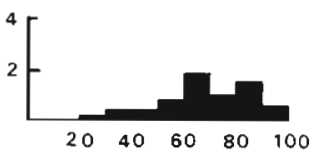

Fig. 5. Distribution of the most common epiphytic algae on 30 stems of Amphibolis griffithii (Penguin Island, November 1983) separated into percentile divisions expressed as relative cover (crustose coralline algae) or on a wet weight basis lother species). Species are Hypnea muscitormis, Haliptilon roseum, Laurencia filitormis, Rhodophyllis multipartita, Champia viridis, Polysiphonia sp., Discranema revolutum,

D. cincinnalis and Gloiosaccion brownil

highly calcified colonies that projected laterally from the basal region of the stems, and Celleporariasp., with its distinctive calcereous and spiral architecture, also colonised stems close to the level of the substratum. By contrast, Celleporaria costata formed irregularlyshaped and calcified colonies that were frequently associated with junction regions between the main and lateral stem branches. The remaining bryozoan, Elezerina blainvilli, exhibited a characteristic 3-dimensional branching pattern so that its holdfast regions often formed extensive cross-linkages between stems, leaves and epiphytic macroalgae. Sponges and asci- 


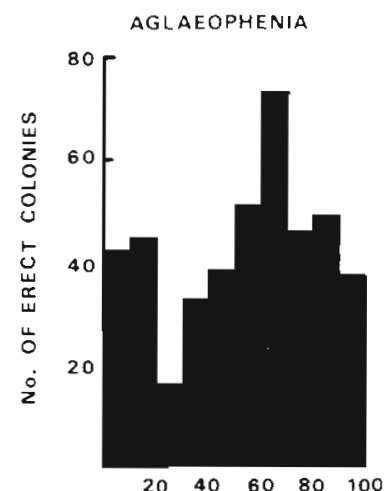

$20 \quad 40 \quad 60 \quad 80 \quad 100$

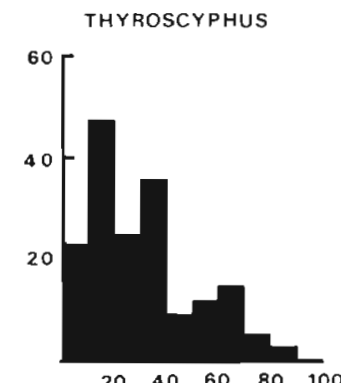

PERCENTILE DIVISIONS OF STEMS dians also occurred at various points along Amphibolis stems but were uncommon.

\section{Leaves}

By comparison with the Amphibolis griffithii stems the epiphytic flora and fauna of the leaves are impoverished. Examination of more than 800 individual leaves in this study showed that while most bore the encrusting coralline algae Fosliella cymodocea and Pneophyllum caulerpae, the area of coverage was very variable. Young (terminal) leaves were generally devoid of any epiphytes, while the area covered by the encrusting coralline algae increased progressively with leaf size (age) and was greater in the lower (older) leaves of a leaf cluster. Area estimates indicated an average of $24.4 \%$ coverage by encrusting coralline algae for all leaves examined in the November 1983 samples from Penguin Island.

Other common epiphytic algae on the leaves were Bornetia binderiana (Sonder) Zanardini, Ceramium puberbulum and Heterosiphonia callithamnion. B. binderiana was attached to the leaf by a small holdfast whereas $H$. callithamnion formed a thin mat over all the leaf surface. Ulva rigida and Bryopsis spp. were accasionally present, and Laurencia cruciata developed as small tufts at the junction between adjacent leaves.

The major sessile epiphytic invertebrates associated with the leaves were the hydroids Plumularia compressa, P. nodosa, Campanularia australis, Amphisbetia minima and Pycnotheca producta, and the bryozoan Thairopora mamillaris. The hydroids, most commonly $P$. compressa and $P$. nodosa, were present on one or both faces of $51.7 \%$ of all leaves examined, and they appeared to colonise the leaves as a series of stolons parallel to the leaf axis in advance of the encrusting coralline algae. $T$. mamillaris formed thin membraneous colonies on the clasping leaf bases and at the inner margins of the individual leaves. Approximately $12 \%$ of leaves or leaf bases were colonised by this bryozoan. Other sessile invertebrates occasionally associated with the leaf blades included the polychaete Spirorbis sp. and a small coral-like bryozoan, Lichenopora sp.

\section{DISCUSSION}

Amphibolis spp. provide a habitat for a greater diversity and larger biomass of epiphytic organisms than any other species of seagrass (Borowitzka \& Lethbridge 1989). The large number of species epiphytic upon
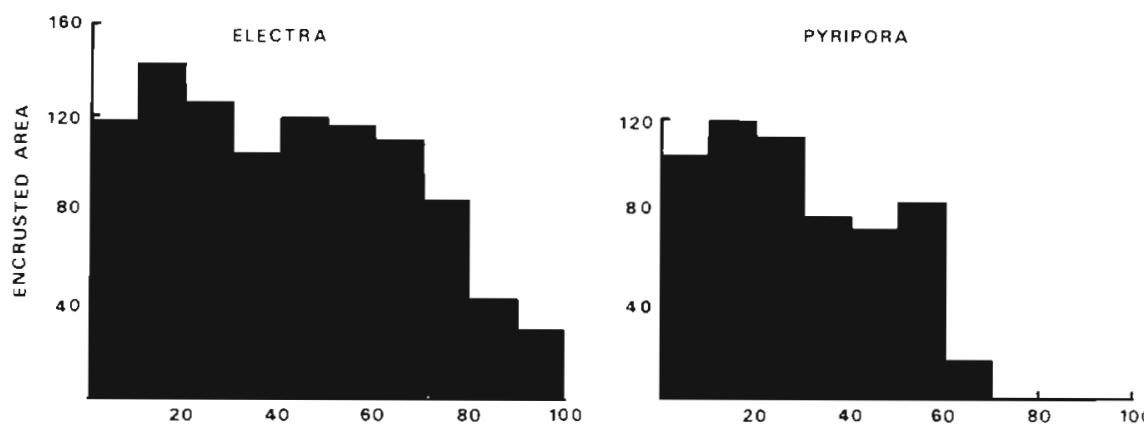

Fig. 7. Distribution of the common epiphytic bryozoans on the same stem samples as Fig. 4, expressed in the same relative cover units used for the crustose coralline algae. Species are Electra flagellum and Pyripora polita 
Amphibolis is probably related to 2 main factors: (1) the coincidence in the distribution of this seagrass genus with one of the world's richest algal floras (Ducker et al. 1977. Womersley 1981); and (2) the morphology of the host plant.

The relatively uniform diameter of the perennial stems and branches contrasts with the terminal clusters of flat leaves which have a turnover period on the order of 3 to 4 mo (Walker 1985). The stems and leaves therefore provide structurally and temporally different habitats for colonisation by epiphytes. Furthermore, the lignified stems survive for several years unlike the leaves of most seagrass species (Borowitzka \& Lethbridge 1989), thus providing a more stable substratum for epiphyte colonization.

As might be anticipated from the different morphologies of these habitats, most of the epiphytes observed on Amphibolis show a distinct preference for either the stems or the leaves of the seagrass. Thus, epiphytes such as Dicranema revolutum, D. cincinnalis, Hymenocladia ramalina, Hypnea spp., Stereotheca elongata, Thyroscyphus marginatus, Electra flagellum and Pyripora polita are almost exclusively restricted to the stems, whereas Bryopsis plumosa, Ulva rigida, Ceramium puberbulum, Plumularia compressa and Thairopora mamillaris are confined to the leaves. A few species, such as Laurencia filiformis, Bornetia binderiana and Metagoniolithon stelliferum, colonise both stems and leaves.

Superimposed upon these gross differences in habitat, there is a finer pattern of distribution with various epiphytes exhibiting preferences for certain positions on the stems and the leaves. For example, Bryopsis plumosa plants are usually found only on the leaf tips, whereas Ceramium puberbulum is most common at the base of the leaves near the leaf junctions. Similarly, there is a distinct apico-basal organisation of the stem epiphytes as shown in Figs. 5 to 7.

Although the long-term species diversity on the stems and the leaves may be similar (cf. Ducker et al. 1977), the stem supports a greater diversity of species than the leaves on any individual Amphibolis griffithii plant. This is presumably a result of the longer life of the stems compared to the leaves, and may also be due to the fact that the stem provides a more diverse habitat (Borowitzka \& Lethbridge 1989). The stems pass from a region of low water-motion and lower irradiance near the substratum, to a high irradiance, high water-motion environment at the seagrass apex. Although insufficient data are available to isolate the relative effects of light and water-motion on epiphyte settlement, recruitment and growth, there is circumstantial evidence to indicate that light is the primary factor influencing algal recruitment and growth. The epiphytic algae dominate the upper portions of the plant where light intensity is highest, and where an effectively greater supply of nutrients is available to the algae through enhanced water movement. Thus the algae may outcompete the sessile epiphytic invertebrates by their more rapid growth in these higher light regions. On the other hand, the filter-feeding epiphytic invertebrates grow well at the base of the stems where there may be less competition with algae due to the lower light environment, and presumably also reduced predation. Foster (1975) reached similar conclusions in his study of algal community development in a Macrocystis pyrifera forest. A similar pattern of distribution of epiphytes has also been observed on artificial Amphibolis-like plants by Lethbridge et al. (1988).

Clearly, the distribution of epiphytic organisms is not random, and this is in keeping with previous observations on the epiphytes of other seagrasses (e.g. Kerneis 1960, Kita \& Harada 1962, van der Ben 1971, Willcocks 1982, Heijs 1985) and the distribution of algae on artificial seagrasses (Tanaka et al. 1984, Horner 1987, Lethbridge et al. 1988).

Although the distribution of epiphytes on Amphibolis plants appears to be strongly influenced by physical factors as has also been observed for Posidonia epiphytes (Horner 1987) and epiphytes on the brown kelp Nereocystis Iuetkeana (Markham 1969), the non-random pattern of recruitment observed in this study may have 2 further causes: (1) the outcome of selective settlement of larvae, spores or propagules; and (2) different degrees of mortality in various areas of the habitat (Underwood 1979, Keogh \& Downes 1982).

At least some of the site preferences observed in this study may result from selective settlement as a number of the epiphytes are exclusively confined to either the stems or the leaves of the seagrass. Although our data do not provide information on the settlement phase, they do describe some features of the subsequent recruitment of epiphytic organisms.

The crustose coralline algae are the primary colonisers of both the leaves and stems of Amphibolis griffithii, as is also the case for other seagrass species (e.g. van den Ende \& Haage 1963, Humm 1964, Bramwell \& Woelkerling 1984). The hydrozoans Plumularia compressa and $P$. nodosa and the bryozoans Thairopora mamillaris, Pyripora polita and Electra flagellum also recruit rapidly on newly available leaves and stems. Together with the crustose coralline algae, these invertebrates are usually observed on all but the youngest plants. The crustose coralline algae seem to act, at least in part, as pioneer plants, possibly providing a suitable substratum for other epiphytes. For example, the geniculate coralline alga Metagoniolithon stelliferum has been reported to settle and grow only on these coralline algae (Ducker 1979, Ducker \& Knox 1984). However, more recent studies by 
Christidis (pers. comm.) show that $M$. stelliferum will settle on coralline algal-free artificial seagrass.

Since most epiphytes on Amphibolis griffithii showed distinct site preferences, the presence of crustose coralline algae is unlikely to promote successful recruitment of most of the epiphytic species. Indeed, surface texture of the substratum is important for numerous species, and many bryozoans prefer to settle upon smooth surfaces (Ryland 1976). On A. griffithiu, the bryozoans Electra flagellum and Pyripora polita are very early colonisers of the smooth lower stem of young plants, often in advance of the encrusting coralline algae. Similarly, Thairopora mamillaris is common on the smooth leaf bases, and Lichenopora sp. appears to settle preferentially on younger leaves which are not conspicuously covered with encrusting coralline algae. The seagrass itself may therefore act primarily as an inert substratum that is physically suitable for epiphy te growth. The observations of Harlin (1973), Sozka (1975), Catteno \& Kalff (1979) and Lethbridge et al. (1988), who compared epiphyte growth on natural vegetation with artificial substrata of similar morphology, support this contention.

The potential impact of grazing animals such as amphipods, gastropods and fish on epiphyte recruitment must not, however, be overlooked. Amphibolis griffithii and its associated epiphytic flora support a large community of such individuals, and these may feed upon epiphytic unicellular algae such as diatoms, the sporelings of macrophytic algae, and members of the sessile invertebrate fauna (Bell et al. 1978, Kitting 1984, Morgan \& Kitting 1984). The importance of particularly micro-grazers on the distribution of the macroflora and fauna has only recently been recognised (e.g. Underwood 1979, Watzin 1983) and needs to be closely examined before conclusions about the primary factors controlling epiphyte recruitment can be established.

If epiphytes are too abundant on the leaves, seagrass photosynthesis in inhibited (Sand-Jensen 1977, Borum \& Wimm-Anderson 1980, Bulthuis \& Woelkerling 1983) and this may eventually lead to death of the seagrass (Ott 1980, Silberstein et al. 1986). At the epiphyte loads observed in this study, this may not be a significant problem for Amphibolis griffithii as its relatively shortlived leaves are regularly shed together with their adherent epiphytes. This strategy is analagous to the epidermis-shedding which occurs in some algae such as Haliptilon roseum (Borowitzka \& Vesk 1978) and Ascophyllum nodosum (Filion-Myklebust \& Norton 1981). On the other hand, the strong, long-lived and essentially non-photosynthetic stems of $A$. griffithii appear to be able to support the epiphyte burdens reported in this study without damage. It is also important to recognise that a relatively dense mass of epiphytic algae acts to reduce water motion within the sea- grass bed, thus decreasing erosion of the sediments below the seagrasses. This may, in part, account for the fact that $A$. griffithii tends to grow in more turbulent areas than other seagrasses such as Posidonia spp. (Cambridge 1975, Shepherd \& Womersley 1981).

Our observations, and those of Ducker et al. (1977) and Kendrick et al. (1988), also show that the species composition and abundance of the epiphytic organisms growing on Amphibolis spp. vary greatly with season and with habitat. This variation does not, however, affect the generality of the observations reported in this paper which provides the basis for further studies of seasonal and spatial variation in Amphibolis epiphytes.

Acknowledgements. We thank Dr Hugh Kirkman for his collaboration in the collection of the Seven Mile Beach samples and Ms A. Wenden for data analysis. Mrs J. Watson and Dr P. E. Brock helped with the identification of hydroids and bryozoans respectively. This study was funded in part by a grant from the MLB Foundation and by Marine Sciences and Technologies Grants Scheme grant 2085 to M.A.B. and R.C.L.

\section{LITERATURE CITED}

Bell, J. D., Burchmore, J. J., Pollard, D. A. (1978). Feeding ecology of a scorpaneid fish, the fortescue Centropogon australis, from a Posidona seagrass habitat in New South Wales. Aust. J. mar. freshwat. Res. 29: 175-185

Borowitzka, M. A., Lethbridge, R. C. (1989). Seagrass epiphytes. In: Larkum, A. W. D., McComb, A. J., Shepherd, S. A. (eds.) Biology of seagrasses, Elsevier, Ansterdam, P. 458-499

Borowitzka, M. A., Vesk, M. (1978). Ultrastructure of the Corallinaceae. I. The vegetative cells of Corallina officinalis and C cuvieri. Mar. Biol. 46: 295-304

Borum, J., Wium-Andersen, S. (1980). Biomass production of epiphytes on eel-graas (Zostera marina L.) in the Oresund, Denmark. Ophelia, Suppl 1: 57-64

Bulthuis, D. A., Woelkerling, W. J. (1983). Biomass accumulation and shading effects of epiphytes on leaves of the seagrass Heterozostera tasmanica, in Victoria, Australia. Aquat. Bot. 16: 137-148

Bramwell, M. D., Woelkerling, W. J. (1984). Studies on the distribution of Pneophyllum-Fosliella plants (Corallinaceae, Rhodophyta) on leaves of the seagrass Amphibolis antarctica (Cymodoceaceae). Aust. J. Bot. 32 131-137

Cambridge, M. L. (1975). Seagrasses of south-western Australia with special reference to the ecology of Posidonia australis Hook. F. in a polluted environment. Aquat. Bot. 1: $149-161$

Cattaneo, A., Kalff, J (1979). Primary production of algae growing on natural and artificial aquatic plants: a study of interactions between epiphytes and their substrate. Limnol. Oceanogr. 24: 1031-1037

Ducker, S. C. (1979). The genus Metagoniolithon Weber-van Bosse (Corallinaceae, Rhodophyta). Aust. J. Bot. 27: $67-101$

Ducker, S. C., Foord, N. J., Knox, R. B. (1977). Biology of Australian seagrasses: the genus Amphibolis C. Agardh (Cymodoceaceae). Aust. J. Bot. 25: 67-95

Ducker, S. C., Knox, R. B. (1984). Epiphytism at the cellular level with special reference to algal epiphytes. In: Lins- 
kens, H. F. Heslop-Harrison, J. (eds.) Encyclopedia of plant physiology, New Series, Vol.17. Springer Verlag, Berlin, p. 113-133

Filion-Myklebust, C. Norton, T. A. (1981). Epidermis shedding in the brown seaweed Ascophyllum nodosum (L.) Le Jolis, and its ecological significance. Mar Biol. Lett. 2: 45-51

Foster, M. S. (1975). Regulation of algal community development in a Macrocystis pyrifera forest. Mar Biol. 32 331-342

Harlin, M. M. (1973). 'Obligate' algal epiphyte: Smithora naidum grows on a synthetic substrate. J Phycol 9: 230-232

Harvey, W. H. (1847). 'Nereis Australis'. Reeve, London

Harvey, W. H. (1855). Some account of the marine botany of the colony of Western Australia. Trans. R. Ir. Acad. 22: 525-566

Heijs, F. M. L. (1985). The seasonal distribution and community structure of the epihytic algae on Thalassia hemprichii (Ehrenb.) Archers from Papua New Guinea. Aquat. Bot 21: $295-324$

Horner, S. M. J. (1987). Similarity of epiphyte biomass dis tribution on Posidonia and artificial seagrass leaves. Aquat. Bot. 27: 159-167

Howard, R. K., Edgar, G. J., Hutchings, P. A. (1989). Faunal assemblages of seagrass beds. In: Larkum, A. W. D., McComb, A. J., Shepherd, S. A. (eds.) Biology of seagrasses. Elsevier, Amsterdam, p. 536-564

Humm, H. J. (1964). Epiphytes of the seagrass Thalassia testudinum in Florida. Bull. mar Sci. Gulf Caribb. 14: 306-341

Joll, L. M., Phillips, B. F. (1984). Natural diet and growth of juvenile western rock lobster Panuliris cygnus George. J exp. Mar. Biol. Ecol. 75: 145-169

Kendrick, G. A., Walker, D. I., McComb, A. J. (1988). Changes in distribution of macro-algal epiphytes on stems of the seagrass Amphibolis antarctica along a salinity gradient in Shark Bay, Western Australia, Phycologia 27. 201208

Kerneis, A. (1960). Contribution a l'étude faunistique et ecologique des herbiers de Posidonies de la region de Banyuls. Vic Milieu 11: 145-187

Keough, M. J., Downes, B. J. (1982). Recruitment of marine invertebrates: the role of active larval choices and early mortality. Oecologia (Berl.) 54: 348-352

Kirkman, H., Walker, D. I. (1989). Regional studies - Western Australian seagrasses. In: Larkum, A. W. D., McComb, A. J., Shepherd, S. A. (eds.) Biology of seagrasses. Elsevier, Amsterdam, p. 157-181

Kita, T., Harada, E. (1962). Studies on the epiphyte conmunities. I. Abundance and distribution of microalgae and small animals on the Zostera blades. Publ. Seto mar biol. Lab. 10: 245-257

Kitting, C. (1984). Selectivity by dense populations of small invertebrates foraging among seagrass blade surfaces. Estuaries 7: 276-288

Klumpp, D. W., Howard, R. K., Pollard, D. A. (1989). Trophodynamics and nutritional ecology of seagrass communities. In: Larkum, A. W. D., McComb, A. J., Shepherd, S. A. (eds.) Biology of seagrasses, Elsevier, Amsterdam, p. $394-457$

This article was submitted to the editor
Lethbridge, R. C., Borowitzka, M. A., Benjamin, K. J. (1988) The development of an artificial Amphibolis-like seagrass of complex morphology and preliminary data on its colonization by epiphytes. Aquat. Bot. 31. 153-168

Markham, J. W. (1969). Vertical distribution of epiphytes on the stipe of Nererocystis luetkeana (Mertens) Postels and Ruprecht. Syesis 2: $227-240$

Morgan, M D., Kitting, C. L. (1984). Productivity and utilization of the seagrass Halodule wrightii and its attached epıphytes. Limnol. Oceanogr. 29: 1069-1076

Nichols, P. D., Klumpp, D. W., Johns, R. B. (1985). A study of food chains in seagrass communities. III. Stable carbon isotope ratios. Aust. J. mar Freshwat. Res. 36: 683-690

Ott, J. A. (1980). Growth and production in Posidonia oceanica (L.) Délile. P.S.Z.N.I: Mar Ecol. 1· 47-64

Ryland, J. S. (1976). Physiology and ecology of marine bryozoans. Adv. mar Biol 14: 285-443

Sand-Jensen, K. (1977). Effect of epiphytes on eelgrass photosynthesis. Aquat. Bot. 3: 55-63

Shepherd, S. A., Womersley, H. B. S. (1981). The algal and seagrass ecology of Waterloo Bay, South Australia. Aquat Bot. 12: 305-371

Silberstein, K., Chiffings, A. W., McComb, A. J. (1986). The loss of seagrass in Cockburn Sound, Western Australia. III. The effect of epiphytes on productivity of Posidonia australia Hook. F. Aquat. Bot. 24: 355-371

Sozka, G. D. (1975). Ecological relations between invertebrates and submerged macrophytes in the lake littoral Ekol. Pol. 23: 593-615

Tanaka, N., Iikura, T., Sugiyama, M., Ohwada, K., Asakawa, A., Kitamura, S. (1984). Seusonal and vertical distributions of attached micro-algae in the artificial seagrass in Ago Bay. Bull. Natl. Res. Inst. Aquaculture 5: 51-62

Underwood, A. J. (1979). Ecology of intertidal gastropods. Adv mar. Res. 16: 111-210

van den Ende, G., Haage, P. (1963). Beobachtungen über den Epiphytenbewuchs von Zostera marina $\mathrm{L}$. an der bretonischen Küste. Botanica mar. 5: 105-110

van der Ben, D. (1971). Les epiphytes des feuilles de Posidonia oceanica Délile sur les côtes francaises de la Mediterranée. Mern. Soc. R. Bot. Belg. 168: 1-101

Walker, D. I. (1985). Correlations between salinity and growth of the seagrass Amphibolis antarctica (Labill.) Sonder \& Aschers, in Shark Bay, Western Australia, using a new method for measuring production rate. Aquat. Bot. 23 $13-26$

Watzin, M. C. (1983). The effects of meiofauna on settling macrofauna: meiofauna may structure macrofaunal communities. Oecologia (Berl.) 59: 163-166

Willcocks, P. A. (1982). Colonization and distribution of the red algal epiphytes Melobesia mediocris and Smithora naiadum and the seagrass Phyllospadix torreyi. Aquat. Bot. 12: 365-373

Womersley, H. B. S. (1981). Biogeography of Australasian marine algae. In: Clayton, M. N., King, R. J. (eds.) Marine botany: an Australasian perspective. Longman Cheshire, Melbourne, p. 292-307

Manuscript first received: August 17, 1989

Revised version accepted: April 9, 1990 